\title{
Ecological importance of bacterivorous, pigmented flagellates (mixotrophs) in the Bay of Aarhus, Denmark
}

\author{
Harry Havskum*, Bo Riemann \\ The International Agency for ${ }^{14} \mathrm{C}$ Determination, VKI Water Quality Institute, Agern Allé 11, DK-2970 Horsholm, Denmark
}

\begin{abstract}
Abundance and bacterivory of mixotrophic flagellates were examined in a vertical profile during 1 wk in June 1992 in the Bay of Aarhus, Denmark. A stable pycnocline separated an upper water mass with low salinity, low inorganic nutrient concentration $\left(<0.1 \mu \mathrm{mol} \mathrm{l}^{-1}\right)$ and low bacterial abundance $\left(<10^{6} \mathrm{ml}^{-1}\right)$ from a bottom water mass with higher salinity, inorganic nutrient concentration, and bacterial abundance $\left(>10^{6} \mathrm{ml}^{-1}\right)$. In the upper layer, bacterivorous, pigmented flagellates (mixotrophs) accounted for $49 \%$ of the pigmented biomass. In addition to their function as primary producers, mixotrophic flagellates were responsible for $86 \%$ of the entire flagellate bacterivory. The abundance of bacterial food particles $\left(<10^{6} \mathrm{ml}^{-1}\right)$ was probably not sufficient to sustain growth of most bacterivorous, colourless flagellates, and the nutrient-depleted water body prevented the strict phototrophs from dominating the environment. Below the pycnocline, nutrients were present, bacterial abundance exceeded $10^{6} \mathrm{ml}^{-1}$, and mixotrophic flagellates made up only $9 \%$ of the pigmented biomass and accounted for $19 \%$ of the flagellate bacterivory.
\end{abstract}

KEY WORDS: Marine plankton Mixotrophic flagellates · Colourless flagellates · Bacterivory Mixotrophic biomass - Microbial food web

\section{INTRODUCTION}

The combination of phagotrophy and photosynthesis in single individuals (mixotrophy in the restricted sense, as defined for flagellates by Sanders 1991a) had already been described in the first half of this century (Pascher 1917, Biecheler 1936). The ecological role of natural populations of mixotrophic flagellates, on the other hand, is a new research field, and our present understanding is mainly based on laboratory experiments.

Experiments with the mixotrophic flagellate Poterioochromonas malhamensis revealed that this flagellate relied primarily on phagotrophy. As long as the particulate food abundance was high, photosynthesis did not contribute more than $7 \%$ to the flagellate's carbon budget, irrespective of light intensity. With bacteria as the only food particles, an abundance of $<10^{6} \mathrm{ml}^{-1}$ led

\footnotetext{
-E-mail: hha@vki.dk
}

to an increase of chlorophyll a (chl a) content per cell when the culture was grown in light, and photosynthesis then became the main source of the flagellate's nutrition (Sanders et al. 1990).

Other mixotrophic flagellates, e.g. Chrysochromulina brevifilum, rely primarily on photosynthesis. Limitation of photosynthesis by either light or an inorganic nutrient (phosphate) led to an increase in phagotrophy (Jones et al. 1993). In contrast to Poterioochromonas malhamensis, the particulate food abundance had no effect on C. brevifilum's chl a content per cell (Jones et al. 1995).

It is often assumed that bacteria are mainly consumed by colourless nanoflagellates (Azam et al. 1983, Andersen \& Fenchel 1985, McManus \& Fuhrman 1986. Baretta-Bekker et al. 1994). Recently, there has been increasing evidence from natural environments that this is not always the case. and that grazing by nigmented flagellates can be the major cause of bacterial mortality (see below). Some pigmented flagellates have also been reported to be important grazers of 
nano-sized organisms (Bockstahler \& Coats 1993 a, b, Olrik \& Nauwerck 1993).

In natural environments with reduced light intensity, mixotrophic flagellates have been observed as important grazers of bacteria (e.g. Bird \& Kalff 1986, 1987, 1989, Sanders et al. 1989, Bennett et al. 1990, Berninger et al. 1992, Hall et al. 1993).

Only a few records exist of mixotrophic flagellates as important bacterial grazers from natural environments with low inorganic nutrient concentrations (e.g Nygaard \& Tobiesen 1993, Arenovski et al. 1995).

Little is known about the relationships between bacterial abundance and colourless and pigmented grazers in natural environments. Arenowski et al. (1995) observed an increase in the abundance of colourless flagellates after addition of glucose, nitrogen, and phosphorus to oligotrophic water samples, a phenomenon presumably coupled to an increase in bacterial abundance from $<0.5 \times 10^{\circ}$ to $>2 \times 10^{\circ} \mathrm{ml}$. The abundance and grazing impact of mixotrophic flagellates decreased in the same treatments. In contrast, in surface waters of Boston Harbor (Massachusetts, USA), Epstein \& Shiaris (1992) counted approximately as many pigmented, bacterivorous flagellates as colourless flagellates at an abundance of $2.2 \times 10^{6}$ bacteria $\mathrm{ml}^{-1}$. Growth of bacterivorous flagellates does not seem to be limited when the bacterial abundance exceeds $2 \times 10^{6} \mathrm{ml}^{-1}$ (Fenchel 1982).

The objective of this study was to examine the abundance of bacteria and phytoplankton and to determine the grazing activities of bacterivorous, pigmented, and colourless flagellates in a stratified coastal ecosystem. By means of microscopical examinations and shortterm uptake experiments using natural bacterial tracers, the importance of mixotrophic flagellates as primary producers and bacterivores was evaluated respectively by comparison of their biomass with the biomass of the remaining pigmented organisms and by comparison of their grazing impact on bacteria with that of the colourless flagellates

\section{MATERIALS AND METHODS}

Study site. This study was carried out during the period 8 to 14 June 1992 from the Norwegian RV 'Håkon Mosby', which was anchored at Stn 4 in the

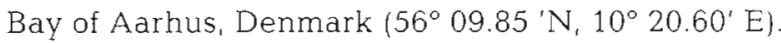

During the experimental period, there was a stable pycnocline at approximately 10 to $11 \mathrm{~m}$ depth, which separated an upper layer with low salinity and low nitrate and phosphate concentrations from a nutrientrich bottom layer with higher salinity. The water temperature was $18^{\circ} \mathrm{C}$ at $3 \mathrm{~m}$ and $8^{\circ} \mathrm{C}$ at $16 \mathrm{~m}$. Stratification occurs in the Bay of Aarhus during the major part of the year, especially in spring and summer (Christiansen et al. 1994). Further details on chemical and physical analyses were presented by Thingstad et al. (1996b).

Water samples were collected daily from 3, 11, and $16 \mathrm{~m}$ depths between 09:00 and 10:00 h. On June 11, a vertical study was carried out using samples collected at $3,7,9,11,13$, and $16 \mathrm{~m}$ depths. A diel study was carried out on 12-13 June using samples collected at $3 \mathrm{~m}$ depth at 10:00, 16:00, 22:00, 06:00 and 10:00 h. All samples were collected without prefiltration.

Microscopic determination of phytoplankton carbon biomass and bacterivory. Phytoplankton organisms (including colourless flagellates and phototrophic ciliates) > approximately $8 \mu \mathrm{m}$ were usually identified, enumerated, and measured on an Olympus inverted microscope using water samples fixed in Lugol's solution (HMSO 1990). Dinoflagellates <20 $\mu \mathrm{m}$ and other organisms < approximately $8 \mu \mathrm{m}$ when stained with Lugol's solution could not always be differentiated into colourless and pigmented organisms with certainty and were therefore identified, measured, and enumerated on an Olympus $\mathrm{BH} 2$ epifluorescence microscope with $1250 \times$ magnification. Water samples for epifluorescence microscopy were fixed with aldehydefixative' $20 \%$ paraformaldehyde, $15 \%$ glucose and $25 \%$ glutaraldehyde) in a 1:9 mixture with the seawater (recipe, Marine Biological Laboratory, Helsingør, Denmark). Unstained, DAPI (4',6-diamidino-2-phenylindole)-stained, and acridine-orange-stained subsamples were filtered onto 0.2 and $0.8 \mu \mathrm{m}$ black polycarbonate filters (diameter $25 \mathrm{~mm}$ ) on the sampling day and stored at $-30^{\circ} \mathrm{C}$ to preserve the chlorophyll autofluoresence (Hobbie et al. 1977. Porter \& Feig 1980, Bloem et al. 1986). The dominating Prymnesiophyceae were identified on a JEOL JEM-100 SX electron microscope. Whole mounts for electron microscopy (EM) were made from all water samples using the procedures described by Moestrup \& Thomsen (1980) and Thomsen (1982).

The organisms were assigned to up to 26 different groups according to their mode of nutrition (see below), motility, and taxonomic relationships. At least 100 cells or colonies of each of up to 26 groups in each water sample were enumerated, and 20 of each group in each sample were measured. Cell volume was calculated by assigning the organisms to simple geometric shapes and by measuring 1 or 2 dimensions. For all protists, except diatoms, cell volume = plasma volume For diatoms, plasma volume = cell volume - vacuole volume (Strathmann 1967). Plasma volume $\left(\mu \mathrm{m}^{3}\right)$ was converted to carbon biomass (pg) with a factor $0.13 \mathrm{pg}$

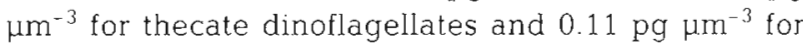
all other organisms (Mullin et al. 1966, BMEPC-HC 1988). Carbon biomass for the different groups was 
calculated from the cell abundance of each group and the carbon per cell content.

According to their mode of nutrition, the microorganisms were classified as strictly heterotrophic (colourless) flagellates, mixotrophic flagellates (in the restricted sense, as a combination of bacterivory and phototrophy), and other phototrophic organisms (where possible mixotrophy, e.g. the combination of herbivory and phototrophy, was not included in this investigation).

Bacterivory was determined according to the procedure described by Sherr et al. (1987). Fluorescently labelled, heat-killed bacteria (FLB) were prepared from naturally occurring bacteria of the same location by $0.8 \mu \mathrm{m}$ prefiltration and concentration of a 20 l. water sample on a Minitan ultrafiltration system. Subsamples of the raw water samples collected daily were filled in clear, acid-washed $100 \mathrm{ml}$ glass bottles, placed in containers on deck, covered by nets to create the approximate in situ light intensities, and continuously bathed in water pumped up from the corresponding depths. The subsamples remained untreated for $1 \mathrm{~h}$ to let the microbial community recover from the handling shock. Subsequently, FLB were added, resulting in a final FLB abundance of approximately $30 \%$ of the natural bacterial abundance. Incubations lasted 0 and $20 \mathrm{~min}$ (see also Sherr et al. 1988). FLB-samples were fixed with $4 \%$ ice-cold glutaraldehyde (EM quality), at a 1:1 mixture to avoid particle egestion, filtered onto $0.8 \mu \mathrm{m}$ black polycarbonate membrane filters (diameter $25 \mathrm{~mm}$ ), and stored at $-30^{\circ} \mathrm{C}$ (Sanders et al. 1989). FLB uptake was enumerated using an epifluorescence microscope equipped with a blue-light filter set. Flagellate clearance rates were calculated from per-cell ingestion rates of FLB and the FLB abundance in each water sample. Net uptake of FLB was calculated by inspecting flagellates for association with FLB after 20 min of incubation and by subtracting the values from time-zero inspections. Uptake was significant when the $95 \%$ confidence intervals of time-zero and time-20-min estimates did not overlap: $P_{20}-1.96\left[P_{20}\right.$ $\left.\left(1-P_{20}\right) / n_{20}\right]^{1 / 2}>P_{0}+1.96\left[P_{0}\left(1-P_{0}\right) / n_{0}\right]^{1 / 2}$, where $P$ is the number of FLB associated with a cell, and $n$ the number of cells inspected, at time-20-min and timezero respectively (confidence interval of the mean, Rice 1988). At least 100 cells (maximum 800 cells) of each bacterivorous flagellate group were inspected in each sample (with at least 30 ingested FLB per group for the groups with significant uptake). Less than 30 ingested FLB were counted per group for the group Dinobryon spp. on 9,10, and 12 June at $3 \mathrm{~m}$ depth and for the Prymnesiophyceae $<5 \mu \mathrm{m}$ on 13 and 14 June at $16 \mathrm{~m}$ depth. Ingestion and clearance rates were calculated on a species level for only 1 species, Telonema subtile. Other bacterivorous species occurred either in low numbers and/or could not always be separated with certainty from species that appeared to be similar under the epifluorescence microscope. Similar species were put into the same group, and clearance rates were presented on a generic level, i.e. Dinobryon spp. or class level, i.e. Prymnesiophyceae $<5 \mu \mathrm{m}$, Prymnesiophyceae $>5 \mu \mathrm{m}$ and Pedinellophyceae or on a functional group level, i.e. colourless flagellates $4-8 \mu \mathrm{m}$. Cells of the dominating species in these groups displayed bacterivory, but not all cells included in these groups were necessarily bacterivorous. Group and total flagellate community bacterivory in each water sample was derived from the per-cell clearance rates of each group for FLB, the abundance of flagellates from each bacterivorous group, and the natural bacterial abundance (Sherr et al. 1989).

Bacterivory by organisms other than flagellates was not included in the calculation of total bacterivory. The biomass of potentially bacterivorous ciliates never exceeded $2 \%$ of the protist biomass, as estimated every second day (O. H. Haslund pers. comm., unpubl. data).

Bacterial carbon biomass and production. The bacterial carbon biomass was derived from cell counts (Hobbie et al. 1977) and measurements of cell volume (Lee \& Fuhrman 1987), using a carbon content of $0.35 \mathrm{pg} \mathrm{C} \mathrm{mm}^{-3}$ (Bjørnsen 1986). A minimum number of 400 cells were counted, 50 cells per filter were measured, and the size was calibrated against fluorescent microspheres (Polysciences Inc, Warrington, PA, USA) 0.22 to $1.0 \mu \mathrm{m}$ in diameter. Bacterial production was calculated by using the procedures for thymidine incorporation described by Fuhrman \& Azam (1980): briefly, duplicate samples of $10 \mathrm{ml}$ were incubated at in situ temperatures for $20 \mathrm{~min}$ using $10 \mathrm{nM}{ }^{3} \mathrm{H}$ thymidine $\left(20 \mu \mathrm{Ci} \mathrm{nmol}{ }^{-1}\right.$, New England Nuclear, Boston). Blanks were prepared from samples to which buffered formalin had been added ( $1 \%$ in the final solution). For estimation of the total bacterial production, samples were filtered onto $0.45 \mu \mathrm{m}$ Sartorius membrane filters (25 mm diameter, cellulose nitrate) after incubation and washed thoroughly with 5\% ice-cold trichloroacetic acid (TCA). To calculate cell production from incorporation, a conversion factor of $1.1 \times 10^{18}$ cells $\mathrm{mol}^{-1}$ thymidine into TCA precipitate was used (Riemann et al. 1987).

\section{RESULTS}

\section{Vertical phytoplankton distribution}

Throughout the period, there was a marked difference in phytoplankton community structure between the layers above and below the pycnocline. On 11 June, the pycnocline was between 10 and $11 \mathrm{~m}$ depth, 

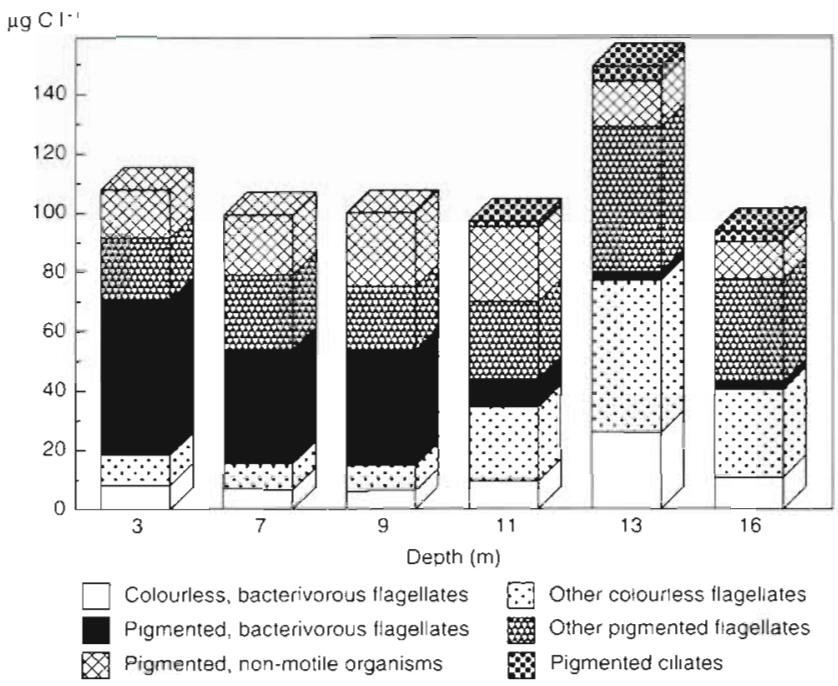

Fig. 1 Phytoplankton carbon biomass (including colourless flagellates), bascd on a vertical study on 11 June, 16:00 h

but further down or higher up on other days (Thingstad et al. in press b). The vertical distribution from 11 June (Fig. 1) illustidies the difference between the 2 laycrs: In the upper layer, approximately half of the pigmented biomass was composed of mixotrophs, whereas they accounted for only a minor part of the pigmented biomass in the bottom layer. Pigmented ciliates were only found below the pycnocline, and both bacterivorous, colourless flagellates and colourless flagellates feeding exclusively on organisms larger than bacteria were more abundant below than above the pycnocline (Fig. 1).

The daily water samples from $11 \mathrm{~m}$ contained water from the upper or the bottom layer to a varying degree, since the pycnocline was not always exactly at the same depth. In the analysis of the microbial processes and biomasses (see below) the 3 and $16 \mathrm{~m}$ depths were selected to illustrate the vertical extremes.

\section{Pigmented groups}

The pigmented biomass was dominated by pigmented flagellates at 3 and at $16 \mathrm{~m}$ depth (Fig. 2). The most striking difference between the 2 water layers, however, was the percentage of pigmented, bacterivorous flagellates (mixotrophs). On average for all 7 samplings, mixotrophic flagellates accounted for about half $(49 \%)$ of the pigmented biomass at $3 \mathrm{~m}$ depth, but for only $9 \%$ at $16 \mathrm{~m}$ depth (Fig. 2). Pigmented flagellates that took up FLB belonged to the classes Chrysophyceae, Prymnesiophyceae, and Pedinellophyceae (Fig. 2). Mixotrophic Chrysophyceae, i.e. Dinobryon balticum and Dinobryon cf. faculiferum (diverging from the description of the type species by its very short stalk) were only observed above the pycnocline and accounted for $3( \pm 1) \%$ of the pigmented biomass (Fig. 2). Prymnesiophyceae were found both above and below the pycnocline, but the species composition was quite different: the most abundant Prymnesiophyceae in the upper layer were Chrysochromulina brachycylindra and Chrysochromulina minor, both $<5 \mu \mathrm{m}$. Prymnesiophyceae $<5 \mu \mathrm{m}$ accounted for 39 $( \pm 16) \%$ of the pigmented biomass at $3 \mathrm{~m}$ depth. Prymnesiophyceae $>5 \mu \mathrm{m}$, mainly Chrysochromulina cf. ericina/hirta, were also found at $3 \mathrm{~m}$ depth, but were less numerous, $1( \pm 1) \%$ of the pigmented biomass. Below the pycnocline, Prymnesiophyceae $<5 \mu \mathrm{m}$ accounted for $3( \pm 2) \%$ of the pigmented biomass. The dominating species was Imantonia rotunda. The bacterivorous Pedinellophyceae, mainly Pseudopedinella tricostata and Pseudopedinella sp. (with 6 chloroplasts), were found both above and below the pycnocline, accounting for approximatcly $6 \%$ of the pigmented biomass in both water layers (Fig. 2).

Other pigmented flagellates, which made up on the average $35 \%$ of the pigmented biomass at $3 \mathrm{~m}$ and $60 \%$ at $16 \mathrm{~m}$, could not be shown to be mixotrophic (Fig. 2). The most important of these pigmented flagellates were the Dinophyceae, which accounted for 24 $( \pm 10) \%$ of the pigmented biomass above the pycnocline and for $40( \pm 13) \%$ below. Dinophysis spp. were only found in the upper layer, whereas species belonging to the genera Ceratium, Micracanthodinium, Gymnodinium, Heterocapsa, Prorocentrum, and the Diplopsalis group among others were found in the whole

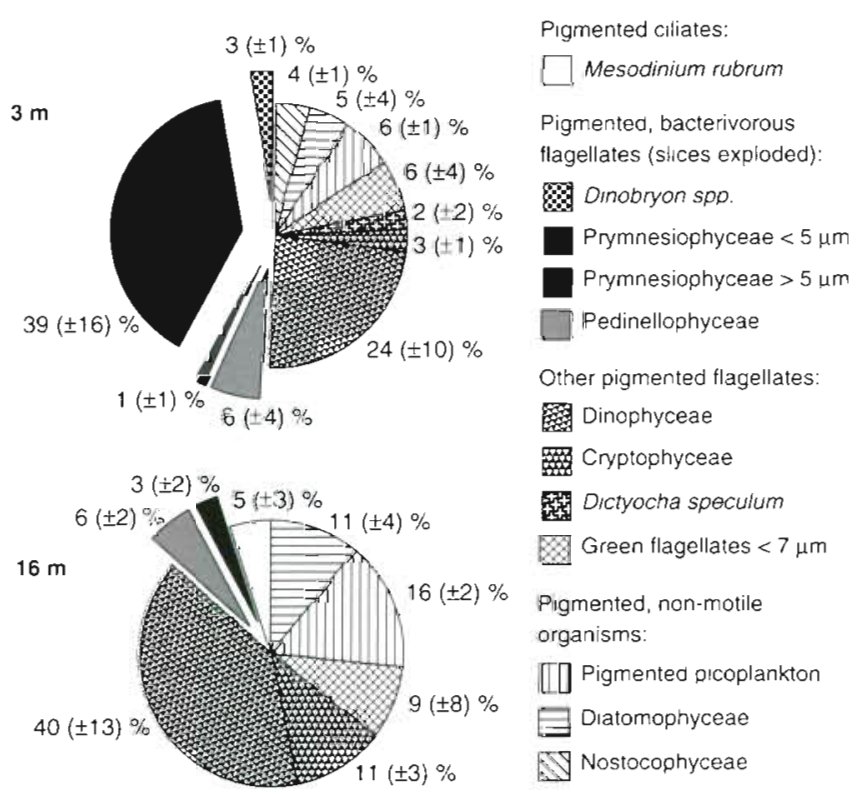

Fig. 2. Average biomass percentages of pigmented organism groups at 3 and $16 \mathrm{~m}$ depths, for water samples taken each day, 8 to 14 June, 10:00 h (SD in parentheses) 
water column. None of these dinoflagellates took up FLB. Although these pigmented dinoflagellates were not bacterivorous, the possibility that some of them were mixotrophic cannot be excluded, since no uptake experiments with nano-sized tracer particles were performed (see review by Riemann et al. 1995). The remaining pigmented flagellates were Cryptophyceae spp., green flagellates $<7 \mu \mathrm{m}$, and the naked stage of Dictyocha speculum (Fig. 2); no uptake of FLB was observed.

Pigmented, non-motile organisms on the average accounted for $15 \%$ of the pigmented biomass at $3 \mathrm{~m}$ and for $27 \%$ at $16 \mathrm{~m}$ depth (Fig. 2). The Diatomophyceae were mainly Rhizosolenia spp., and Skeletonema costatum. The pigmented picoplankton organisms were mainly cyanobacteria. Larger Nostocophyceae were sparse, and colony-forming Chroococcales occurred only above the pycnocline. Diatomophyceae and Nostocophyceae have not been reported to be phagotrophic.

Virtually all pigmented ciliates, which were present only below the pycnocline, were Mesodinium rubrum and accounted for $5( \pm 3) \%$ of the pigmented biomass; no uptake of FLB was observed.

\section{Phagotrophic groups}

The most abundant colourless flagellate, Leucocryptos marina, which accounted for $41( \pm 11) \%$ of all colourless flagellates' biomass above the pycnocline and $42( \pm 16) \%$ below the pycnocline, did not take up FLB in our experiments (Fig. 3). Instead, L. marina was frequently (5 to $20 \%$ of all cells, data not shown)

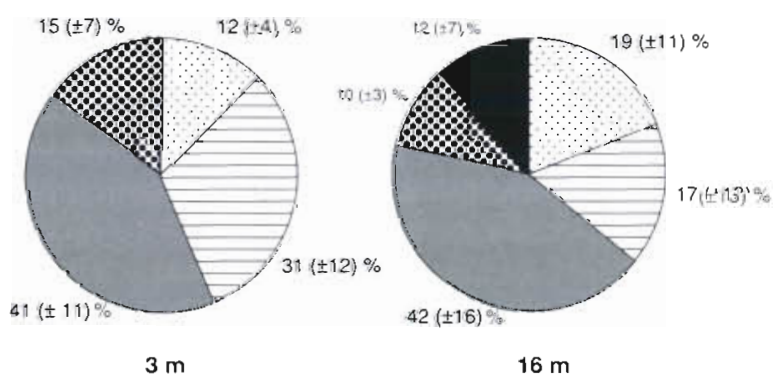

Bacterivorous colourless flagellates: Non-bacterivorous colourless flagellates:

Colourless flagellates $4-8 \mu \mathrm{m}$

Telonema subtile 11-14 $\mu \mathrm{m}$

Leucocryptos marina 11-18 $\mu \mathrm{m}$

Dinophyceae 10-20 بm

Dinophyceae $>20 \mu \mathrm{m}$

Fig. 3. Average biomass percentages of colourless flagellate groups at 3 and $16 \mathrm{~m}$ depths, for water samples taken each day, 8 to 14 June, 10:00 h (SD in parentheses) observed with ingested pigmented organisms, mainly of the nano-size fraction.

Other colourless flagellates that did not take up FLB were dinoflagellates. The larger species, $>20 \mu \mathrm{m}, \mathrm{i}, \mathrm{e}$. Gyrodinium spirale/lachryma, Protoperidinium spp., and Cochlodinium spp. were only observed below the pycnocline and accounted for $12( \pm 7) \%$ of the colour-

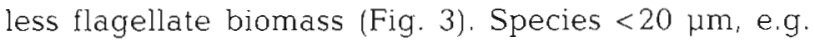
Gymnodinium spp., Gyrodinium spp., were observed over the whole water column; on average, they made up $15( \pm 7) \%$ of the colourless flagellate biomass at $3 \mathrm{~m}$ and $10( \pm 3) \%$ at $16 \mathrm{~m}$ depth (Fig. 3).

The remaining colourless flagellates were assigned to 2 groups, Telonema subtile and colourless flagellates $4-8 \mu \mathrm{m}$, and 10 to $30 \%$ of the cells in these 2 groups were observed with ingested FLB (data not shown). These bacterivorous, colourless flagellates accounted for $43 \%$ of the colourless flagellate biomass above and for $36 \%$ below the pycnocline (Fig. 3).

Bacterivorous, pigmented flagellate groups have been mentioned under pigmented groups (see above). Bacterivorous flagellates from all groups were also occasionally observed with ingested pigmented organisms (data not shown). For the bacterivorous, colourless flagellates, these food organisms included both cyanobacteria and eukaryotic algae. In the bacterivorous, pigmented flagellates, on the other hand, the only pigmented food organisms that could be identified with certainty were cyanobacteria, which because of their yellow/orange autofluorescence could be differentiated from the predators' plastids, which had a red autofluorescence. Eukaryotic organisms could have been food items for the mixotrophic flagellates as well (for review, see Riemann et al. 1995). Most pigmented, eukaryotic organisms have a red autofluorescence, however, and a certain differentiation between the potential prey's plastids and the mixotroph's own plastids was not possible.

\section{Bacterivory rates}

For the flagellate groups colourless flagellates $4-8 \mu \mathrm{m}$, Telonema subtile, Prymnesiophyceae $<5 \mu \mathrm{m}$, Prymnesiophyceae $>5 \mu \mathrm{m}$, and Pedinellophyceae, uptake of FLB was significant in all experiments (Table 1). The pigmented flagellate group Dinobryon spp. had also significant uptake of FLB on 5 sampling days, but insignificant uptake on 10 and 12 June at $3 \mathrm{~m}$ depth (data not shownj. Since uptake of FLB was significant on the majority of the sampling days, the group Dinobryon spp. was defined as mixotrophic and always included in the calculations of mixotrophic biomass. On average, the group Dinobryon spp. accounted for only $6 \%$ of the mixotrophic biomass at $3 \mathrm{~m}$ depth (Fig. 2). 
Table 1. Average FLB (fluorescently labelled, heat-killed bacteria) ingestion rates, clearance rates, and grazing rates on bacteria for various bacterivorous flagellate groups at 3 and $16 \mathrm{~m}$ depths, based on experiments between 10:00 and 11:00 h on each day 8-14 June. "Mixotrophic groups

\begin{tabular}{|c|c|c|c|c|}
\hline $\begin{array}{l}\text { Bacterivorous group, } \\
\text { average cell volume }\end{array}$ & $\begin{array}{l}\text { FLB ingestion rate } \\
\left(\text { FLB flag. }{ }^{-1} \mathrm{~h}^{-1}\right)\end{array}$ & $\begin{array}{l}\text { Clearance rate } \\
\left.\text { (nl flag }{ }^{-1} h^{-1}\right)\end{array}$ & $\begin{array}{c}\text { Clearance rate } \\
\left(\mathrm{pl} \text { flag. }-\mu \mathrm{m}^{-3} \mathrm{~h}^{-1}\right)\end{array}$ & $\begin{array}{l}\text { Grazing rate } \\
\text { (bacteria flag. }{ }^{-1} \mathrm{~h}^{-1} \text { ) }\end{array}$ \\
\hline \multicolumn{5}{|l|}{$3 \mathrm{~m}$ depth, $18^{\circ} \mathrm{C}$} \\
\hline -Prymnesiophyceae $<5 \mu \mathrm{m}, 33 \mu \mathrm{m} \mathrm{s}^{.}$ & 0.24 & 0.9 & 28 & 0.8 \\
\hline - Dinobryon spp., $45 \mu \mathrm{m}^{3}$ & 0.12 & 0.4 & 9.3 & 0.4 \\
\hline - Prymnesiophyceae $>5 \mu \mathrm{m}, 110 \mu \mathrm{m}^{3}$ & 0.21 & 0.8 & 7.1 & 0.7 \\
\hline - Pedinellophyceae, $170 \mu^{3}$ & 0.93 & 3.6 & 21 & 2.9 \\
\hline Colourless flagellates $4-8 \mu \mathrm{m}, 120 \mu^{3}$ & 1.2 & 4.2 & 38 & 4.1 \\
\hline Telonema subtile, $460 \mu \mathrm{m}^{3}$ & 0.72 & 2.8 & 6.0 & 2.3 \\
\hline \multicolumn{5}{|l|}{$16 \mathrm{~m}$ depth, $8^{\circ} \mathrm{C}$} \\
\hline - Prymnesiophyceae $<5 \mu \mathrm{m}, 14 \mu^{3}$ & 0.15 & 0.4 & 29 & 0.5 \\
\hline - Pedinellophyceae, $100 \mu^{3}$ & 0.30 & 0.8 & 8.0 & 1.0 \\
\hline Colourless flagellates $4-8 \mu \mathrm{m}, 110 \mu \mathrm{m}^{3}$ & 0.78 & 2.3 & 21 & 2.9 \\
\hline Telonema subtile, $540 \mu^{3}$ & 2.8 & 7.9 & 15 & 10 \\
\hline
\end{tabular}

Telonema subtile's average clearance rate for bacteria was lower above the pycnocline than below (Table 1). In contrast, Pedinellophyceae and colourless flago! lates $4-8 \mu \mathrm{m}$ had on the average higher clearance rates at $3 \mathrm{~m}$ than at $16 \mathrm{~m}$ depth (Table 1). For the Prymnesiophyceae $<5 \mu \mathrm{m}$ the average clearance rate was approximately the same above as below the pycnocline (Table 1). Dinobryon spp. and Prymnesiophyceae $>5 \mu \mathrm{m}$ were only abundant in the upper layer, and their clearance rates for FLB were rather low compared to other flagellates (Table 1).

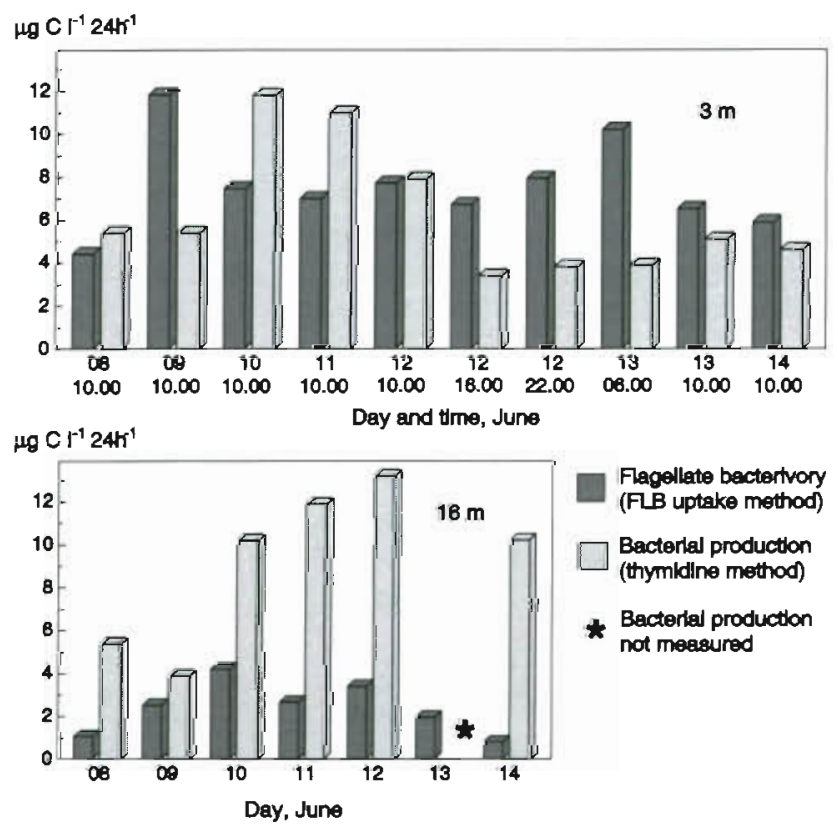

Fig. 4. Flagellate bacterivory and bacterial production at 3 and $16 \mathrm{~m}$ depths, 8 to 14 June, 10:00 h, other times indicated

\section{Bacterivory, bacterial production, and bacterial abundance}

Above the pycnocline, the average flagellate bacterivory measured with the FLB uptake method, 7.6 $( \pm 2.0) \mu \mathrm{g} \mathrm{Cl}^{-1} \mathrm{~d}^{-1}$, was on average slightly higher than the bacterial production measured by the thymidine method, $6.2( \pm 2.8) \mu \mathrm{g} \mathrm{C} \mathrm{^{-1 }} \mathrm{d}^{-1}$ (Fig. 4), which can be compared to the continuous decline of the bacterial abundance in this layer from approximately 1.2 to $0.6 \times$ $10^{6} \mathrm{ml}^{-1}$ (Fig. 5).

At $16 \mathrm{~m}$, the estimated average bacterial production, $9.1( \pm 3.4) \mu \mathrm{g} \mathrm{C} \mathrm{l}^{-1} \mathrm{~d}^{-1}$, was considerably higher than the estimated average flagellate bacterivory, $2.4( \pm 1.1)$ $\mu \mathrm{g} \mathrm{Cl} \mathrm{l}^{-1} \mathrm{~d}^{-1}$. That means that flagellates, as estimated, only grazed about one quarter of the bacteria produced. At the same time, the bacterial abundance at 16 $m$ depth varied between 1 and $1.6 \times 10^{6} \mathrm{ml}^{-1}$, without showing a general trend (Fig. 5).

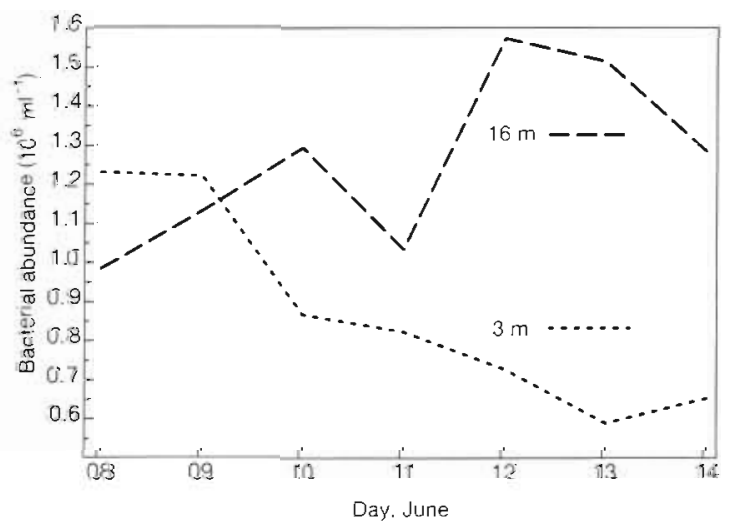

Fig. 5. Bacterial abundance at 3 and $16 \mathrm{~m}$ depths, 8 to 14 June, 10:00 h 

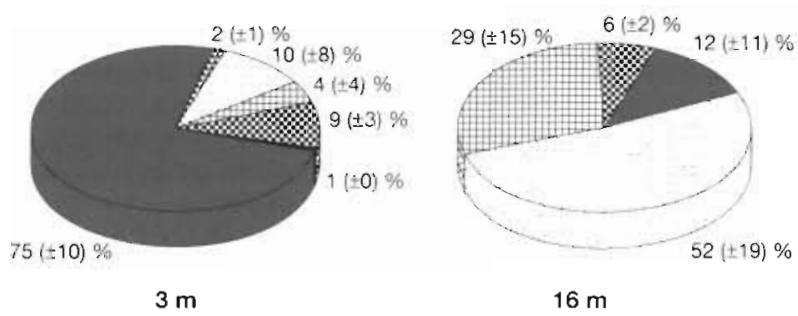

Dinobryon spp: Drymnesiophyceas $<5 \mu \mathrm{m}$.

Xedinellophyceae' Helonema subtile

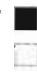

Prymmesiophyceae > 5 pim ${ }^{*}$ Colourless flagellates $4-8$,

Fig. 6. Average flagellate bacterivory percentages of bacterivorous flagellate groups, for water samples taken each day, 8 to 14 June, 10:00 h (SD in parentheses). "Mixotrophic groups

The average bacteria size was similar throughout the water column, $0.098( \pm 0.016) \mu^{3}$ above and 0.095 $( \pm 0.009) \mu \mathrm{m}^{3}$ below the pycnocline.

Bacterial mortality due to grazing by pigmented and colourless flagellates was considerably different between the 2 layers (Fig. 6): mixotrophic flagellates were responsible for $86( \pm 11) \%$ of the flagellate grazing on bacteria above, but only for $19( \pm 12) \%$ below the pycnocline. At $3 \mathrm{~m}$, the most important bacterivores were the $<5 \mathrm{\mu m}$ Prymnesiophyceae $75( \pm 10) \%$, while at $16 \mathrm{~m}$ the colourless flagellates $4-8 \mu \mathrm{m}$ were the most important bacterivores $52( \pm 19) \%$

\section{DISCUSSION}

The significance of mixotrophic flagellates as primary producers and bacterivores was evaluated: mixotrophic flagellates accounted for $49 \%$ of the pigmented biomass and were responsible for $86 \%$ of the flagellate bacterivory in the nutrient-depleted upper layer. In contrast, mixotrophic flagellates made up only $9 \%$ of the pigmented biomass and accounted for $19 \%$ of the total flagellate bacterivory below the pycnocline. where nutrients were present and the bacterial abundance was higher.

Previous studies have also demonstrated the abundance of bacterivorous, pigmented flagellates in surface seawater, Epstein \& Shiaris (1992) measured uptake of FLB by ciliates and pigmented and colourless nanoflagellates in surface water samples taken from Boston Harbor, USA. Nanoflagellates consumed 10\% and ciliates $6 \%$ of the bacterial standing stock per day. The average flagellate clearance rates calculated by Epstein \& Shiaris (1992) ranged from 5.3 to $14.6 \mathrm{nl}$ flagellate $^{-1} \mathrm{~h}^{-1}$, somewhat higher than in the present investigation at $3 \mathrm{~m}$ depth $\left(0.4\right.$ to $4.2 \mathrm{nl}$ flagellate ${ }^{-1} \mathrm{~h}^{-1}$, Table 1 ). On the basis of the abundance of natural bacteria $\left(2.2 \times 10^{6} \mathrm{ml}^{-1}\right)$ and of different colourless and pigmented bacterivorous protist groups and the protist clearance rates for FLB as reported by Epstein \& Shiaris (1992), we calculated that mixotrophic flagellates were responsible for $59 \%$ of the flagellate bacterivory and $33 \%$ of the total protist bacterivory. Mixotrophic flagellates were thus also important bacterivores in surface seawater of Boston Harbor. In the present study, where the bacterial abundance at $3 \mathrm{~m}$ depth was lower (on average $0.9 \times 10^{6} \mathrm{ml}^{-1}$ ), mixotrophic flagellates were even more important as bacterivores $186 \%$ of the flagellate bacterivory). Mineral nutrient concentrations in Boston Harbor were not reported by Epstein \& Shiaris (1992) and the mixotrophs' importance as primary producers is difficult to evaluate, since no information was given about the abundance of pigmented picoplankton, pigmented non-motile nanoplankton, and pigmented microplankton. On the other hand, each pigmented nanoflagellate group included cells that displayed bacterivory in the study by Epstein \& Shiaris (1992), and the 3 most important bacterivorous, pigmented species accounted for $93 \%$ of the total pigmented nanoflagellate abundance.

Nygaard \& Tobiesen (1993) performed FLB uptake experiments using water samples taken during a bloom of Prymnesiophyceae in 1989 in a coastal area of Western Norway. The mixotrophic flagellates Prymnesium parvum and Chrysochromulina ericina grazed 3.4 to 18 bacteria flagellate ${ }^{-1} \mathrm{~h}^{-1}$ in the phosphatedepleted upper water layer $(<0.05 \mu \mathrm{M})$, while no bacterivory by the Prymnesiophyceae could be measured at $4 \mathrm{~m}$ and downwards, where the phosphate concentration was higher. The grazing rates reported by Nygaard \& Tobiesen (1993) were higher than the average grazing rates measured for mixotrophic flagellates in the present study $\left(0.4\right.$ to 2.9 bacteria flagellate ${ }^{-1} \mathrm{~h}^{-1}$, Table 1). The bacterial abundance was not reported by Nygaard \& Tobiesen (1992), nor was the grazing impact on bacteria by colourless flagellates. Rather, total bacterivory was estimated by uptake of radiolabelled bacteria (RLB) by cells retained on a $1.0 \mu \mathrm{m}$ filter Comparisons of the results obtained by the FLB and RLB uptake methods led to the estimation that the mixotrophic Prymnesiophyceae were responsible for up to $60 \%$ of the total grazing on bacteria down to $4 \mathrm{~m}$. The only information given about the significance of the mixotrophs as primary producers was the fact that $P$. parvum and $C$. ericina were blooming, which does not necessarily mean that the Prymnesiophyceae dominated the pigmented biomass. Although the investigation by Nygaard \& Tobiesen (1993) was less detailed, the results were in accordance with those obtained in the present study: mixotrophs were important bacterial grazers and important primary producers in nutrientdepleted surface seawaters.

Arenovski et al. (1995) examined the distribution and abundance of mixotrophs during 2 cruises in the 
Sargasso Sea, using long time incubations with FLB $(6$ and $24 \mathrm{~h}$ ). Although only 1 group was examined for uptake of FLB, the pigmented nanoplankton, and no grazing rates were determined, the general findings were in accordance with the results obtained in the present study: in the oligotrophic surface waters (1 to $5 \mathrm{~m})$, pigmented nanoplankton organisms that displayed bacterivory were always abundant, and on 2 occasions, $50 \%$ were observed with ingested tracers. In all incubations of water samples collected from deeper layers (below $100 \mathrm{~m}$ ), where nutrient concentrations were higher, less than $0.5 \%$ of the pigmented nanoplankton was observed with ingested FLB.

In contrast to our results, McManus \& Fuhrman (1986) did not find a significant uptake of inert, fluorescent particles by pigmented flagellates. The inorganic nutrient concentration and the bacterial abundance in the water sample collected from $3 \mathrm{~m}$ depth in central Long Island Sound (USA) were not reported.

In summary, including the present investigation, 4 of the 5 studies on mixotrophs (see above) demonstrated that bacterivorous, pigmented organisms were present in surface seawater. When bacteria uptake rates were measured, pigmented flagellates were responsible for the majority of the flagellate bacterivory in 3 of 4 cases. The nutrient status of the surface water was only indicated in 3 investigations, where the concentration of 1 or several inorganic nutrients was low, and mixotrophic flagellates were abundant. Comparisons between the mixotrophic flagellates' share of the total flagellate bacterivory and bacterial abundance could only be made in 2 cases: flagellate bacterivory was absolutely dominated by mixotrophs $(86 \%)$ at low bacterial abundance $\left(0.9 \times 10^{6} \mathrm{ml}^{-1}\right)$ and was less dominated by mixotrophs (59\%) at higher bacterial abundance $\left(2.2 \times 10^{6} \mathrm{ml}^{-1}\right)$.

\section{Biomass estimates of bacterivorous flagellates}

Not all cells of a species in the same environment necessarily have the same nutrient status, but we assumed that when cells of a species displayed bacterivory at one time, other cells of the same species will be bacterivorous at other times. In the present study, we put all cells that displayed bacterivory into groups with similar cells of the same species and possibly also of similar species which could not be separated by epifluorescence microscopy. Typical cells of the dominating 1 or 2 bacterivorous species accounted for $>90 \%$ of the cells in a group. The remaining cells were slightly divergent in cell size, shape, or colour, and were either atypical cells of the dominating species or other similar species that possibly were not bacterivorous. The consequence of this strategy is that the biomass of bac- terivorous colourless and bacterivorous pigmented flagellates could have been overestimated. As an example, colourless flagellates feeding exclusively on detritus or organisms larger than bacteria may have been included in the group colourless flagellates $4-8$ $\mu \mathrm{m}$ and strict phototrophic Prymnesiophyceae may have been included in the group Prymnesiophyceae $<5 \mu \mathrm{m}$, owing to their similarity in epifluorescence microscopical preparations to species that displayed bacterivory. A possible overestimation would include all those cells that did not display bacterivory. If the biomass of bacterivorous pigmented flagellates was restricted to those that displayed phagotrophy through their uptake of FLB after 20 min of incubation, the biomass would have comprised on average only $5 \%$ of the pigmented biomass at $3 \mathrm{~m}$ depth and $1 \%$ at $16 \mathrm{~m}$ depth (data not shown). In contrast, adding the biomass of pigmented cells that displayed bacterivory to the biomass of other cells of the same species or similar species that had not taken up FLB after 20 min of incubation resulted in a mixotrophic biomass which was $49 \%$ at $3 \mathrm{~m}$ depth and $9 \%$ at $16 \mathrm{~m}$ depth. Similarly, the colourless flagellates that displayed bacterivory accounted only for $11 \%$ of the total colourless flagellate biomass at $3 \mathrm{~m}$ depth and for $9 \%$ at $16 \mathrm{~m}$ depth (data not shown), compared to the $43 \%$ and $36 \%$ respectively derived from adding the biomass of all cells included in the bacterivorous colourless flagellate groups. If the biomass of bacterivorous pigmented and colourless flagellates was overestimated, the clearance rates would be proportionally underestimated, whereas the reported grazing impact on bacteria by pigmented and colourless flagellates would remain unaffected.

On the other hand, bacterivorous species that were not numerous enough to be enumerated separately and species with a very low grazing impact on bacteria (time-20-min FLB uptake not significantly different from time-zero association with FLB) could have been included in non-bacterivorous groups. The degree of a possible underestimation is not known. Theoretically, all flagellates that did not take up FLB at significant rates could have taken up bacteria at very low rates. Large flagellates $(>10 \mu \mathrm{m})$ may preferably have fed on nano-sized prey, but may have taken up bacteria occasionally. Pigmented flagellates without significant uptake of FLB may mainly be phototrophic, but occasional ingestion of bacteria may have occurred. Records of bacterivory by pigmented flagellates have been published for almost all algal classes (see review by Riemann et al. 1995). In contrast, non-motile organisms, e.g. Diatomophyceae, Nostocophyceae, and pigmented non-motile picoplankton, have so far not been observed to display phagotrophy and can be excluded as possible bacterivores. Pigmented flagel- 
lates accounted for $85 \%$ of the pigmented biomass at $3 \mathrm{~m}$ depth and for $69 \%$ at $16 \mathrm{~m}$ depth (Fig. 2). The potential underestimation of mixotrophic biomass was thus highest at $16 \mathrm{~m}$ depth (see above). Although ingestion of bacteria, even at rates unmeasurable with the FLB uptake method, may be important for some pigmented flagellates, e.g. the acquisition of vitamins (Sanders 1991b), their grazing impact on bacteria would still be negligible.

\section{Flagellate bacterivory estimates}

Although flagellate bacterivory estimates derived from fluorescent particle uptake experiments are rather precise, with a standard deviation between replicates of $<20 \%$ (Sherr et al. 1989, authors' unpubl. data), the accuracy of such results is still unknown: e.g. Bodo sp. ingested bacteria-sized latex beads considerably less efficiently than bacteria (Nygaard et al. 1988); Paraphysomonas vestita preferred living to heat-killed bacteria of similar size and morphology (Landry et al. 1991); and for Epipyxis pulchra, the selection and rejection process of different food particles has been described in detail (Wetherbee \& Andersen 1992). In contrast, the growth rates of mixed flagellate cultures were not different with FLB or unstained, viable bacteria of the same strain as food source (Sherr et al. 1987). The discrimination capacity between different food particles apparently is species-specific. Even though we assumed that results in this investigation, based on uptake experiments using heat-killed and stained, natural bacteria as a food source, are better than those derived from the use of inert particles, the use of tracer particles can only be an attempt to reflect the real world, since the prey quality changes during the labelling process. On the other hand, at present we can do no better, and so far the FLB uptake method is the only well-established approach for discriminating between uptake by pigmented and by colourless flagellates in natural environments.

In the present study, the results of FLB uptake experiments revealed that all pigmented, bacterivorous flagellates were $<10 \mu \mathrm{m}$. These mixotrophs were on average responsible for $86 \%$ of the flagellate bacterivory at $3 \mathrm{~m}$ depth and for $19 \%$ at $16 \mathrm{~m}$ depth (Fig. 6). The group colourless flagellates $4-8 \mu \mathrm{m}$ accounted for 10 and $52 \%$ of the flagellate bacterivory at 3 and $16 \mathrm{~m}$ depths respectively (Fig. 6). The only nanoflagellate $>10 \mu \mathrm{m}$ that took up FLB was Telonema subtile (length 11 to $14 \mu \mathrm{m}$ ), which accounted for only $4 \%$ of the flagellate bacterivory at $3 \mathrm{~m}$ depth and for $29 \%$ at $16 \mathrm{~m}$ depth (Fig. 6).

Total flagellate bacterivory was on average higher (7.6 $\mu \mathrm{g} \mathrm{C}^{-1} \mathrm{~d}^{-1}$ ) than the bacterial production at $3 \mathrm{~m}$ depth (6.2 $\mu \mathrm{g} \mathrm{C}^{-1} \mathrm{~d}^{-1}$ ) (Fig. 4). Assuming that the water masses at the vertical extremes, 3 and $16 \mathrm{~m}$ depths, were stable (Thingstad et al. 1996b), the observed continuous decline of the bacterial abundance during the study period to approximately half of the initial values can explain this difference (Fig. 5). In contrast, at $16 \mathrm{~m}$ depth flagellate bacterivory corresponded to only one quarter of the bacterial production (Fig. 4), and no dramatic rise in bacterial abundance was observed during the period (Fig. 5). The 'mismatch' between flagellate bacterivory and bacterial production at $16 \mathrm{~m}$ depth is not necessarily the result of an underestimation of the flagellate bacterivory through the FLB uptake method. Some immediate examples for the possible fate of the remaining bacteria would be bacterial sinking losses (Pedrós-Alió \& Mas 1993), viral lysis (Weinbauer \& Peduzzi 1995), or grazing by other organisms, e.g. copepod nauplii (Roff et al. 1995). Sinking losses and viral activity were probably the most qualified candidates in the bottom layer, since the zooplankton $>20 \mu \mathrm{m}$ did not include a significant proportion of bacterivores (O. H. Haslund unpubl. data). The observed 'mismatch' could also result from an overestimate of the bacterial production, since a fixed conversion factor was used to calculate bacterial production from rates of thymidine incorporation (Riemann et al. 1987, Hollibaugh 1988).

The flagellate bacterivory estimates in this study were based on the important fact that the most abundant, colourless nanoflagellate, Leucocryptos marina (11-18 $\mu \mathrm{m})$, did not take up FLB (Fig. 3), contrary to the usual assumption that colourless nanoflagellates are the most important bacterivores (Azam et al. 1983, Andersen \& Fenchel 1985, McManus \& Fuhrman 1986 , Baretta-Bekker et al. 1994). L. marina was in fact occasionally observed with ingested pico-sized cyanobacteria in its food vacuoles (data not shown). Assuming that $L$. marina did not reject FLB owing to their nature, but simply did not select FLB because of their small size $(<1 \mu \mathrm{m})$, then $L$. marina must have had its lower boundary for prey size just in between the cyanobacteria $>1 \mu \mathrm{m}$ and the heterotrophic bacteria $<1 \mu \mathrm{m}$. L. marina was frequently observed with pigmented organisms in its food vacuoles, mainly of the nano-size fraction (5 to $20 \%$ of all $L$. marina cells, data not shown). We do not know if L. marina was also feeding on detritus or small colourless protists, since these particles have no autofluorescence, but we believe that particles $>1 \mu \mathrm{m}$ constituted its food source. The prey:predator size ratio for flagellates other than dinoflagellates seems to range from 2:1 to 16:1 (Hansen et al. 1994 and references therein). Assuming that L. marina was not cannibalistic, and that its upper prey size was below its own cell size, then the biomass ratio between L. marina and potentially suitable food organ- 

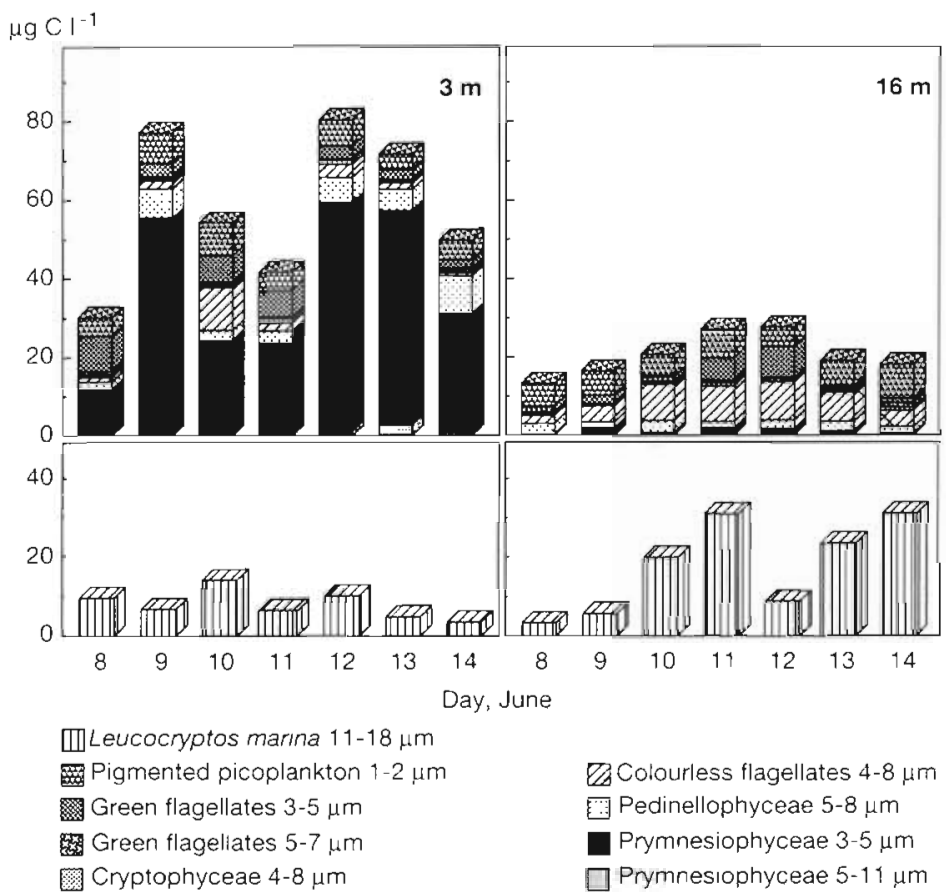

Q Colourless flagellates $4-8 \mu \mathrm{m}$ Pedinellophyceae 5-8 $\mu \mathrm{m}$ - Prymnesiophyceae 3-5 $\mu \mathrm{m}$ $\square$ Prymnesiophyceae 5-11 $\mu \mathrm{m}$

Fig. 7. Carbon biomass of Leucocryptos marina and of its potential prey in the range $1-11 \mu \mathrm{m}$ at 3 and $16 \mathrm{~m}$ depths, $8-14$ June, 10:00 h colourless nanoflagellate biomass both above and below the pycnocline (Fig. 3). The most important bacterivorous flagellates were $<10$ $\mu \mathrm{m}$, accounting for respectively 96 and $71 \%$ of the flagellate bacterivory above and below the pycnocline (Fig. 6). Similarly, Sherr \& Sherr (1991) reported that bacterivorous flagellates were mainly at the lower end of the 2-20 $\mu \mathrm{m}$ size spectrum, whereas larger flagellates typically fed on prey larger than bacteria. In ecological models, colourless flagellates $>10 \mu \mathrm{m}$ should be defined as mainly non-bacterivorous phytoplankton feeders. Flagellates in the range 2-10 $\mu \mathrm{m}$ and not in the broader range 2-20 $\mu \mathrm{m}$ should be defined as the major bacterivores, and mixotrophic flagellates should be included.

\section{Phagotrophic efficiency of different bacterivorous groups}

Thingstad et al. (1996a) assumed that an idealized colourless fiageliate, being a specialized phagotroph, has a higher affinity for bacteria than a mixotrophic flagellate. In a mixotrophic flagellate, the organelles involved in photosynthesis would reduce the potential space available for vacuoles, which should have an upper limit in protists with respect to the percentage of total cell volume (Nisbet 1984).

The results from the Bay of Aarhus (Table 1) did not show a clear-cut difference in phagotrophic efficiency between the 2 types of flagellates, as assessed by calculating the volume-specific clearance rates (Fenchel 1991): the mixotrophic flagellate groups had bacteria clearance rates in the range 7.1 to $28 \mathrm{pl}$ flagellate$\mu \mathrm{m}^{-3} \mathrm{~h}^{-1}$ at $3 \mathrm{~m}$ depth and 8 to $29 \mathrm{pl}$ flagellate- $\mu \mathrm{m}^{-3} \mathrm{~h}^{-1}$ at $16 \mathrm{~m}$ depth. The corresponding values for colourless flagellates were 6 to 38 and 15 to 21 pl flagellate- $\mu \mathrm{m}^{-3}$ $\mathrm{h}^{-1}$ at respectively 3 and $16 \mathrm{~m}$ depths. Other studies, e.g. Epstein \& Shiaris (1992), could not demonstrate a different phagotrophic efficiency for mixotrophic and colourless flagellates either.

Among all bacterivorous flagellate groups, cells were observed with pigmented organisms in their food vacuoles (data not shown). Clearance rates for FLB did thus not reflect maximal clearance rates for particulate food in general, but only the actual grazing impact on bacteria in nature. For example Telonema subtile's clearance rates for bacteria were on average lower above than below the pycnocline $(2.8$ compared to 7.9 nl flagellate ${ }^{-1} \mathrm{~h}^{-1}$, Table 1), although it has been demonstrated that metabolic processes are faster at $18^{\circ} \mathrm{C}$ (the temperature at $3 \mathrm{~m}$ depth) than at $8^{\circ} \mathrm{C}$ (the temperature at $16 \mathrm{~m}$ depth) (Sherr et al. 1988, Choi \&

3). All non-bacterivorous, colourless nanoflagellates were $>10 \mu \mathrm{m}$ and accounted for more than half of the 
Peters 1992). Patterson et al. (1993) noted that $T$ subtile fed on other protists and detritus. Small protists were more abundant above than below the pycnocline (Fig. 7), and they may have constituted a larger part of $T$ subtile's diet at $3 \mathrm{~m}$ depth, which would explain the lower average bacteria clearance rate at $3 \mathrm{~m}$ depth.

Even though there are species-specific differences between flagellates, there is a general tendency of increasing prey size with increasing predator size, e.g. in this study, most colourless flagellates $>10 \mu \mathrm{m}$ did not feed on bacteria, but on larger prey (see also Fenchel 1988, Sherr \& Sherr 1991, Hansen et al. 1994). In the Bay of Aarhus, the bacterivorous, colourless flagellates were generally larger than the mixotrophic flagellates (Table 1), implying that the bacterivorous colourless flagellates fed on larger prey $(>1 \mu \mathrm{m})$ to a higher extent than the mixotrophs. Similar bacteria clearance rates of the 2 types of flagellates is thus not proof that mixotrophic flagellates have the same phagotrophic efficiency as the colourless flagellates. In addition, mixotrophy must still represent a metabolic cost in terms of energy used for maintaining the capability of photosynthesis.

Although all bacterivorous groups were feeding on larger organisms as well, the reported bacteria clearance rates in the present study, ranging from 0.4 to 7.9 nl flagellate ${ }^{-1} \mathrm{~h}^{-1}$ (Table 1) were similar to those reported for flagellates from natural marine environments by athers using fluorescent particle uptake methods, with rates ranging from 0.5 to $14.6 \mathrm{nl}$ flagellate $^{-1} \mathrm{~h}^{-1}$ (McManus \& Fuhrman 1986, Sherr et al. 1989, Epstein \& Shiaris 1992, Hall et al. 1993, McKenzie et al. 1995).

\section{Food abundance threshold for bacterivores}

The exact particulate food abundance threshold for sustaining growth of colourless flagellates is not known. For flagellates feeding exclusively on cultured bacteria, a threshold in the range 0.5 to $2 \times 10^{6}$ bacteria $\mathrm{ml}^{-1}$ has been reported (Fenchel 1982). Cultured bacteria are usually larger than naturally occurring bacteria; the ones used by Fenchel (1982) had an average cell volume of $0.6 \mu^{3}$, about 6 times larger than the bacteria in this study. The results obtained in laboratory studies of sea water samples from the Bay of Aarhus (Andersen \& Fenchel 1985) indicate that a minimum bacterial abundance of 1 to $1.5 \times 10^{6} \mathrm{ml}^{-1}$ could sustain the growth of bacterivorous, colourless flagellates. The bacterial dimensions were, however, not measured and since the water samples were filtered, additional substrates could have increased the average bacterial cell size (Li \& Dickie 1985). In addition, the particulate food threshold might be different for vari- ous flagellate species depending on their feeding mode. For example Paraphysomonas feeds through direct interception, while Pteridomonas is a filter feeder (Fenchel 1991). Zubkov \& Sleigh (1995) demonstrated that Paraphysomonas imperforata ceased to feed below $1 \times 10^{6}$ bacteria $\mathrm{ml}^{-1}$ In contrast, Pteridomonas danica consumed maximal numbers of bacteria at an abundance above $0.5 \times 10^{6}$ bacteria $\mathrm{ml}^{-1}$, and continued to catch bacteria even below this abundance.

With an average bacterial cell volume of $0.1 \mu^{3}$, an average bacterial abundance of $0.9 \times 10^{6} \mathrm{ml}^{-1}$ above the pycnocline, and an average bacterial abundance of $1.3 \times 10^{6} \mathrm{ml}^{-1}$ below the pycnocline, the bacterial biomass was probably below the prey abundance threshold that solely can support the growth of most flagellates in both cases. Although this idea cannot be proved, we believe that supporting evidence comes from the observation that no flagellate seemed to rely exclusively on bacterivory. The mixotrophic flagellates combined bacterivory with photosynthesis, and bacterivorous colourless flagellates were also feeding on nano-sized organisms (data not shown). The smallest colourless flagellates were 5 to 10 times larger than the smallest mixotrophs (Table 1), possibly because they also had to be able to feed on organisms larger than bacteria to survive. Since the bacterial abundance was lower at 3 than at $16 \mathrm{~m}$ depth, food limitation for flagellates that relied mainly on bacterivory was potentially more severe above than below the pycnocline.

In conclusion, we found that mixotrophic flagellates constituted half of the pigmented biomass in the nutrient-depleted top layer of the Bay of Aarhus. These mixotrophs were also responsible for almost the entire flagellate grazing on bacteria. The bacteria were grazed down to a low level, $<1 \times 10^{6} \mathrm{ml}^{-1}$, and our results strongly suggest that no flagellate group was able to sustain its growth solely on bacterivory. The majority of the colourless nanoflagellates did not feed on bacteria at all, and the bacterivorous colourless flagellates were also observed with ingested eukaryotes. In the deeper, nutrient-rich environment, bacterivorous pigmented flagellates accounted, on average, for only $9 \%$ of the pigmented biomass. Here bacterial abundance was higher and colourless flagellates were mainly responsible for the grazing on bacteria. The high abundance of bacterivorous, pigmented flagellates in a nutrient-depleted environment support evidence from theoretical modelling on the role of mixotrophic flagellates (Thingstad et al. 1996a). The results obtained in the present study also advocate for a conceptual integration of mixotrophic flagellates into the organic matter dynamics in the sea and suggest that the mixotrophic compartment be included in the discussion of plankton nutrient limitation. 
Acknowledgements. We thank Prof. H. A. Thomsen for comments on the identification of Prymnesiophyceae, and L. T Haukrogh and $W$. Martinsen for technical assistance. This study was supported in part by MAST II contract (MAS2CT92-0031 - MEICE). The Danish Research Academy (grant 383/8/92 to H.H.), and The Danish Strategic Environmental Programme (Project no. 4.27)

\section{LITERATURE CITED}

Andersen P, Fenchel T (1985) Bacterivory by microheterotrophic flagellates in seawater samples. Limnol Oceanogr 30(1): 198-202

Arenovski AL, Lim EL, Caron DA (1995) Mixotrophic nanoplankton in oligotrophic surface waters of the Sargasso Sea may employ phagotrophy to obtain major nutrients. J Plankton Res 17(4):801-820

Azam F, Fenchel $T$, Field JG, Gray JS, Meyer-Reil LA, Thingstad $F$ (1983) The ecological role of water-column microbes in the sea. Mar Ecol Prog Ser 10:257-263

Baretta-Bekker JG, Riemann B, Baretta JW, Rasmussen EK (1994) Testing the microbial loop concept by comparing mesocosm data with results from a dynamical simulation model. Mar Ecol Prog Ser 106:187-198

Bennett SJ, Sanders RW, Porter KG (1990) Heterotrophic, autotrophic and mixotrophic nanoflagellates: seasonal abundances and bacterivory in a eutrophuc lake. Limnol Oceanogr 35:1821-1832

Berninger UG, Caron DA, Sanders RW (1992) Mixotrophic algae in three ice-covered lakes of the Pocono Mountains, U.S.A. Freshwat Biol 28:263-272

Biecheler B (1936) Observation de la capture et de la digestion des proies chez un Péridınien vert. C R Séances Soc biol 122:1173-1175

Bird DF, Kalff J (1986) Bacterial grazing by planktonic lake algae. Science 231:493-495

Bird DF, Kalff J (1987) Algal phagotrophy: regulating factors and importance relative to photosynthesis in Dinobryon (Chrysophyceae). Limnol Oceanogr 32:277-284

Bird DF, Kalff J (1989) Phagotrophic sustenance of a metalimnetic phytoplankton peak. Limnol Oceanogr 34:155-162

Bjørnsen PK (1986) Automatic determination of bacterioplankton biomass by image analysis. Appl Environ Microbiol 51:1199-1204

Bloem J, Bär-Glissen MJB, Cappenberg TE (1986) Fixation, counting, and manipulation of heterotrophic nanoflagellates. Appl Environ Microbiol 52(6):1266-1272

BMEPC-HC (Baltic Marine Environmental Protection Commission - Helsinki Commission) (1988) Guidelines for the Baltic Monitoring Programme for the third stage, Part D, Biological determinants. Baltic Sea Environment Proceedings No. 27 D, Government Printing Centre, Helsinki p $1-161$

Bockstahler KR, Coats DW (1993a) Spatial and temporal aspects of mixotrophy in Chesapeake Bay dinoflagellates J Eukaryot Microbiol 40(1):49-60

Bockstahler KR, Coats DW (1993b) Grazing of the mixotrophic dinoflagellate Gymnodinium sanguineum on ciliate populations of Chesapeake Bay. Mar Biol 116:477-487

Choi JW, Peters F (1992) Effects of temperature on two psychrophilic ecotypes of a heterotrophic nanoflagellate Paraphysomonas imperforata. Appl Environ Microbiol 58(2):593-599

Christiansen C, Lund-Hansen LC, Skyum P (1994) Hydrografi og stoftransport i Århus Bugt. Havforsk Miljøstyrelsen 39.1. -86
Epstein SS, Shiars MP (1992) Size-selective grazing of coastal bacterioplankton by natural assemblages of pigmented flagellates, colorless flagellates, and ciliates. Microb Ecol 23:211-255

Fenchel T (1982) Ecology of heterotrophic microflagellates. II Bioenergetics and growth. Mar Ecol Prog Ser 8:225-231

Fenchel T (1988) Marine plankton food chains. Ann Rev Ecol Syst 19:19-38

Fenchel T (1991) Flagellate design and function. In: Patterson DJ, Larsen J (eds) The biology of free-living heterotrophic flagellates. The Systematics Association. Spec Vol No. 45 Clarendon Press, Oxford, p 7-19

Fuhrman JA, Azam F (1980) Bacterioplankton secondary production estimates for coastal waters of British Columbia Antarctic, and California. Appl Environ Microbiol 39:1085-1095

Hall JA, Barett DP, James MR (1993) The importance of phytoflagellate, heterotrophic flagellate and ciliate grazing on bacteria and picophytoplankton sized prey in a coastal marine environment. J Plankton Res 15(9): $1075-1086$

Hansen B, Bjornsen PK, Hansen PJ (1994) The size ratio between planktonic predators and their prey Limnol Oceanogr 39 (2):395-403

Hansen PJ (1992) Prey size selection, feeding rates and growth dynamics of heterotrophic dinoflagellates with special emphasis on Gyrodinium spirale. Mar Biol 114 $327-334$

Hobbie JE, Daley RJ, Jaspar S (1977) Use of Nucleopore filters for counting bacteria by fluorescence microscopy. Appl Environ Microbiol 33:1225-1228

Hollibaugh JT (1988) Limitations of the [3-H] thymidine method for estimating bacterial productivity due to thymidine metabolism. Mar Ecol Prog Ser 43:19-30

HMSO (Her Majesty's Stationery Office) (1990) The enumeration of algae, estimation of cell volume, and use in bioassays. Methods for the examination of waters and associated material. HMSO, London

Jacobson DM, Anderson DM (1986) Thecate heterotrophic dinoflagellates: feeding behavior and mechanisms. J Phy. col 22:249-258

Jones HLJ, Durjun P, Leadbeater BSC, Green JC (1995) The relationship between photoacclimation and phagotrophy with respect to chlorophyll a, carbon and nitrogen content, and cell size of Chrysochromulina brevifilum (Prymnesiophyceae). Phycologia 34:128-134

Jones HLJ, Leadbeater BSC, Green JC (1993) Mixotrophy in marine species of Chrysochromulina (Prymnesiophyceae): ingestion and digestion of a small green flagellate. J Mar Biol Ass UK 73:283-296

Landry MR, Lehner-Fournier JM. Sundstrom JA, Fagerness VL. Selph KE (1991) Discrimination between living and heat-killed prey by a marine zooflagellate, paraphysomonas vestita (Stokes). J Exp Mar Biol Ecol 146:139-151

Lee S, Fuhrman JA (1987) Relationships between biovolume and biomass of naturally derived marine bacterioplankton. Appl Environ Microbiol 53:1298-1303

Li WKW, Dickie PM (1985) Growth of bacteria in seawater filtered through $0.2 \mu \mathrm{m}$ Nucleopore membranes: implications for dilution experiments. Mar Ecol Prog Ser 26:245

McKenzie CH, Deibel D, Paranjape MA, Thompson RJ (1995) The marine mixotroph Dinobryon balticum (Chrysophyceae): phagotrophy and survival in a cold ocean. J Phycol 31:19-24

McManus GB, Fuhrmann JA (1986) Bacterivory in seawater studied with the use of inert fluorescent particles. Limnol Oceanogr 31:420-426 
Moestrup $\varnothing$, Thomsen HA (1980) Preparations of shadow cast whole mounts. In: Gantt E (ed) Handbook of physiological methods. Developmental and cytological methods. Cambridge Univ Press, Cambridge, p 385-390

Mullin MM, Sloan PR, Eppley PW (1966). Relationship between carbon content, cell volume, and area in phytoplankton. Limnol Oceanogr 11:307-311

Neuer S, Cowles TJ (1994) Protist herbivory in the Oregon upwelling system. Mar Ecol Prog Ser 113:147-162

Nisbet B (1984) Nutrition and feeding strategies in protozoa. Crown Helm, London, p 1-280

Nygaard K, Børsheim KY, Thingstad TF (1988) Grazing rates on bacteria by marine heterotrophic microflagellates compared to uptake rates of bacteria]-sized monodisperse fluorescent latex beads. Mar Ecol Prog Ser 44:159-165

Nygaard K, Tobiesen A (1993) Bacterivory in algae: a survival strategy during nutrient limitation. Limmnol Oceanogr 38(2):273-279

Olrik K, Nauwerck A (1993) Stress and disturbance in the phytoplankton community of a shallow, hypertrophic lake. Hydrobiologia 249:15-24

Pascher A (1917) Flagellaten und Rhizopoden in ihren gegenseitigen Beziehungen. Arch Protistenkde 38:1-87

Patterson DJ, Nygaard K, Steinberg G, Turley CM (1993) Heterotrophic flagellates and other protists associated with oceanic detritus throughout the water column in the Mid North Atlantic. J Mar Biol Ass UK 73:67-95

Pedrós-Alió C, Mas J (1993) Bacterial sinking losses. In: Kemp PF, Sherr BF, Sherr EB, Cole JJ (eds) Handbook of methods in aquatic microbial ecology. Lewis Publishers, Boca Raton, Florida, p 677-684

Porter KG, Feig YS (1980) The use of DAPI for identifying and counting aquatic microflora. Limnol Oceanogr 25(5): 943-948

Rice JA (1988) Mathematical statistics and data analysis. Wadsworth \& Brooks/Cole Statistics/Probability Series, Pacific Grove, CA, p 1-594

Ruemann B, Bjornsen PK, Newell S, Fallon R (1987) Calculation of cell production of coastal marine bacteria based on incorporation of ${ }^{3} \mathrm{H}$-thymidine. Limnol Oceanogr 32 : $471-475$

Riemann B, Havskum H, Thingstad F, Bernard C (1995) The role of mixotrophy in pelagic environments. In: Joint $J$ (ed) Molecular ecology of aquatic microbes. Springer-Verlag, Berlin, p 87-114

Roff JC, Turner JT, Webber MK, Hopcroft RR (1995) Bacterivory by tropical copepod nauplii: extent and possible significance. Aquat microb Ecol 9:165-175

Sanders RW (1991a) Trophic strategies among heterotrophic flagellates. In: Patterson DJ, Larsen J (eds) The biology of free-living heterotrophic flagellates. The Systematics Association, Special Volume No 45, Clarendon Press, Oxford, p 21-38

Sanders RW (1991b) Mixotrophic protısts in marine and freshwater ecosystems. J Protozool 38(1):76-81
Sanders RW, Porter KG, Bennett SJ, DeBiase AE (1989) Seasonal patterns of bacterivory by flagellates, ciliates, rotifers, and cladocerans in a freshwater planktonic community. Limnol Oceanogr 34:673-687

Sanders RW, Porter KG, Caron DA (1990) Relationship between phototrophy and phagotrophy in the mixotrophic chrysophyte Poterioochromonas malhamensis. Microb Ecol 19:97-109

Sherr BF, Sherr EB (1991) Proportional distribution of total numbers biovolume and bacterivory among size classes of 2-20 $\mathrm{\mu m}$ nonpigmented marine flagellates. Mar Microb Food Webs 5(2):227-237

Sherr BF, Sherr EB, Fallon RD (1987) Use of monodispersed, fluorescently labeled bacteria to estimate in situ protozoan bacterivory. Appl Environ Microbiol 53 (5):958-965

Sherr BF, Sherr EB, Pedrós-Alió C (1989) Simultaneous measurement of bacterioplankton production and protozoan bacterivory in estuarine water Mar Ecol Prog Ser 54: $209-219$

Sherr BF, Sherr EB, Rassoulzadegan F (1988) Rates of digestion of bacteria by marine phagotrophic protozoa: temperature dependence. Appl Environ Microbiol 54(5):1091-1095

Spero HJ (1982) Phagotrophy in Gymnodinium fungiforme (Pyrrhophyta): the peduncle as an organelle of ingestion. J Phycol 18:356-360

Strathmann RR (1967) Estimating the organic content of phytoplankton from cell volume or plasmavolume. Limnol Oceanogr 12:411-418

Thingstad TF, Havskum H, Garde K, Riemann B (1996a) On the strategy of 'eating your competitor' A mathematical analysis of algal mixotrophy. Ecology $77(7): 39-49$

Thingstad TF, Riemann B, Havskum H, Garde K (1996b) Incorporation rates and biomass content of $C$ and $P$ in phytoplankton and bacteria in the Bay of Aarhus (Denmark) June 1992. J Plankton Res 18(1):97-121

Thomsen HA (1982) Planktonic choanoflagellates from Disko Bugt, West Greenland, with a survey of the marine nanoplankton of the area. Meddr Gronland, Biosci 8:1-35

Vørs N (1992) Ultrastructure and autecology of the marine heterotrophic flagellate Leucocryptos marina (Braarud) Butcher 1967 (Katablepharidaceae/Kathablepharidae), with a discussion of the genera Leucocryptos and Katablepharis/Kathablepharis. Eur J Protistol 28:369-389

Weinbauer MG, Peduzzi P (1995). Significance of viruses versus heterotrophic nanoflagellates for controlling bacterial abundance in the northern Adriatic Sea. J Plankton Res 17(9): $1851-1856$

Wetherbee R, Andersen RA (1992) Flagella of a chrysophycean alga play an active role in prey capture and selection. Direct observation on Epipyxis pulchra using image enhanced video microscopy. Protoplasma 166:1-7

Zubkov MV, Sleigh MA (1995) Bacterivory by starved marine heterotrophic nanoflagellates of two species which feed differently, estimated by uptake of dual radioactivelabelled bacteria. FEMS Microbiol Ecol 17(1):57-65

Manuscript first received: November 11, 1995

Revised version accepted: February 15, 1996

This article was submitted to the editor 